\title{
Effects of Methionine Deficiency on the B Lymphocyte and Immunoglobulins of Cecal Tonsil in Cobb Broilers
}

Original Article

\section{-Author(s)}

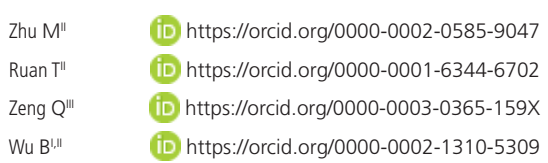

Key Laboratory of Southwest China Wildlife Resources Conservation, Ministry of Education Shida road 1\#, Nanchong, Sichuan, PR China

College of Life Science, China West Norma University, Shida road 1\#, Nanchong, Sichuan, PR China

III Department of Finance Office, China West Normal University, Shida road 1\#, Nanchong, Sichuan, PR China

\section{Mail Address}

Corresponding author e-mail address Bangyuan Wu

China West Normal University Ringgold standard institution - College of Life

Science, Shida road 1\#, Nanchong,

Sichuan, PR China, Nanchong 637002,

China.

Phone: (0202) 01119992240

Email: wubangyuan2008@163.com

\section{Keywords}

B lymphocyte; Cecal tonsil;

Immunoglobulins; Methionine deficiency

\section{ABSTRACT}

The present study was conducted on one-day-old broilers to investigate the effects of methionine deficiency on $B$ lymphocytes and immunoglobulins (slgA, $\lg A$, $\lg G, \lg M$ ) in the cecal tonsil of Cobb broiler chicken. Methods including immunohistochemistry (IHC), western blot $(W B)$, quantitative real-time reverse transcriptase-polymerase chain reaction (qRT-PCR) and Enzyme-Linked Immuno Sorbent Assay (ELISA) were used, and the study lasted for 6 weeks. It was found that the $\lg A^{+} B$ lymphocytes mainly existed in the diffuse lymphoid tissues and lymphoid follicles of the cecal tonsil. The data indicated that the number of $\lg \mathrm{A}^{+}$ $B$ lymphocytes was decreased in the methionine deficiency group, and the WB and qRT-PCR results suggested that the protein and mRNA expression of CD19 were reduced in the methionine deficiency group. Besides, the contents of slgA, IgA, IgG and IgM determined by ELISA decreased in the methionine deficiency group. It could be concluded that methionine deficiency exerts significantly negative effects on the humoral immune function of the intestinal mucosal immunity.

\section{INTRODUCTION}

Methionine is an essential amino acid which possesses high nutritional value and important physiological functions, such as cellular growth and the development of animal (Mirzaaghatabar et al., 2011; Yen et al., 2002), detoxification (Kim et al., 2006), antitumor or anticancer (Horvat et al., 2006; Li et al., 2009), resistance for coccidium infection (Rama Rao et al., 2003) and synthesis of protein (Brosnan, 2006; Tesseraud et al., 2011), etc. Moreover, methionine is closely related to the immune function of livestock and poultry, and is responsible for the regulation of cell function such as oxidation and reduction (Hoshi \& Heinemann, 2010). Appropriate dietary methionine restriction improves colon tight junction barrier function, alters claudin expression pattern and improves epithelial barrier function (Ramalingam et al., 2010).

Methionine deficiency has negative effects on immune organs including thymus, bursa of Fabricus, spleen (Wu et al., 2012a; Wu et al., 2012b; Wu et al., 2013) and small intestine (oxidative stress and apoptosis) (Li et al., 2018; Ruan et al., 2018; Wu et al., 2018a; Wu et al., 2018b). The objective of this study is to determine the effects of methionine deficiency on the $B$ lymphocytes and immunoglobulins in the cecal tonsil of broiler chicken by methods including $I H C, W B$, qRT-PCR and ELISA. Cecal tonsil (CT) is considered to be the largest lymphoid aggregate of avian gut-associated lymphoid tissue (GALT), $\mathrm{CT}$, and elicits protective immune responses against bacterial or viral pathogens in the intestinal tract of avian species (Heidari et al., 2014). Currently, few studies focus on the effects of methionine deficiency on the cecal tonsil in avian, so this research aims to investigate the role of methionine on the important intestinal immune organ - cecal tonsil. 


\section{MATERIALS AND METHODS}

\section{Birds, management and diets}

The animal protocol used in this study was approved by the China West Normal University Animal Care Committee (Nanchong, China), and the study was carried out in accordance with the national standard on the protection of animals used for scientific purposes.

In total, 72 one-day-old male Cobb broiler chicken were used in this study. They were raised at the Research Laboratory of the Department of College of Life Science, China West Normal University in Nanchong (Sichuan, China). The birds were kept in pens on litter, in a cage with a controlled environment. The temperature and lighting programme aligned to the recommendations of national standard (Chinese, GB4925-2010). Briefly, the breeding temperature is controlled at $35-33^{\circ} \mathrm{C}$ in the first week, $33-31{ }^{\circ} \mathrm{C}$ in the second week, $31-28^{\circ} \mathrm{C}$ in the third week, and $28-24{ }^{\circ} \mathrm{C}$ after the fourth week. The relative humidity is between $60 \%$ and $70 \%$, and the concentration of the $\mathrm{CO}_{2}$ should not exceed $0.5 \%$. In addition, plenty of light is also very important to the broiler chicken, on the first and second day, 24 hours of light is needed, and 23 hours from 3 to 6 days. After 7 days the time of light should be kept as 22 to 23 hours per day. It should be noted that the pens should be kept clean (cleaning up the stool in time), and the pens and the other appliances including the sink and feed bucket should be sterilized regularly in order to prevent bacterial contamination and keep the chicks healthy.

The chicken were randomly allotted to 2 groups by body weight $(42 \pm 3 g)$, with 6 replicates pens $(n=6)$ per treatment group. In the methionine deficiency group, broilers were fed diet with methionine (DL-Met) supplementation, while in the control group, chickens were fed on the diet without methionine. All chicken were provided with water as well as aforementioned diets ad libitum. Twenty-four chicks from each small cage were euthanized at 14, 28 and 42 days of age, respectively (twelve in each group at each time point). Cecal tonsils were removed for observation and determination aseptically. Besides, mononuclear cells from the tissues were isolated for further detection.

The total Met content of diets corresponded to the level recommended by NRC (1994). The final concentrations of amino acids, including Met, in the diets were verified analytically (Table 1 ). In Met deficient diet, Met content was $0.26 \%$ for starter diet ( 1 to $21 \mathrm{~d}$ ), and was $0.28 \%$ for Met content in grower diet (22 to $42 \mathrm{~d}$ ). Besides, additional Met contents of $0.24 \%$ and $0.12 \%$ were added to Met deficient diet to produce control diets (starter diet, Met $0.50 \%$; grower diet, Met 0.40\%) (Wu et al., 2012a).

Table 1 - Components of the basal diets for broilers (\%).

\begin{tabular}{|c|c|c|c|c|}
\hline \multirow[b]{2}{*}{ Ingredient, 1 \% } & \multicolumn{2}{|c|}{ Met deficient diet } & \multicolumn{2}{|c|}{ Control diet } \\
\hline & $\begin{array}{c}\text { Starter } \\
\text { diet } \\
1 \text { to } 21 \mathrm{~d}\end{array}$ & $\begin{array}{c}\text { Grower } \\
\text { diet } \\
22 \text { to } 42 d\end{array}$ & $\begin{array}{c}\text { Starter } \\
\text { diet } \\
1 \text { to } 21 \mathrm{~d}\end{array}$ & $\begin{array}{c}\text { Grower } \\
\text { diet } \\
22 \text { to } 42 d\end{array}$ \\
\hline Ground yellow corn & 56 & 59.5 & 56 & 59.5 \\
\hline Soybean meal & 37 & 32.85 & 37 & 32.85 \\
\hline Soybean oil & 3.66 & 4.7 & 3.66 & 4.7 \\
\hline Ground limestone & 0.57 & 0.5 & 0.57 & 0.5 \\
\hline Dicalcium phosphate & 1.8 & 1.6 & 1.8 & 1.6 \\
\hline Salt & 0.3 & 0.3 & 0.3 & 0.3 \\
\hline Choline Chloride & 0.1 & 0.1 & 0.1 & 0.1 \\
\hline DL-Met & 0.0 & 0.0 & 0.24 & 0.12 \\
\hline Bentonite & 0.24 & 0.12 & 0.0 & 0.0 \\
\hline Micronutrients ${ }^{2}$ & 0.33 & 0.33 & 0.33 & 0.33 \\
\hline
\end{tabular}

level, ( \%)

Calculated Nutrients

\begin{tabular}{lcccc} 
ME, MJ/kg & 12.39 & 12.79 & 12.39 & 12.79 \\
CP & 21.17 & 19.72 & 21.17 & 19.72 \\
Lys & 1.19 & 1.08 & 1.19 & 1.08 \\
Met & 0.26 & 0.28 & 0.50 & 0.40 \\
Met+Cys & 0.62 & 0.62 & 0.86 & 0.74 \\
Ca & 0.85 & 0.77 & 0.85 & 0.77 \\
Nonphytate P & 0.44 & 0.40 & 0.44 & 0.40 \\
\hline
\end{tabular}

'Ingredient and nutrient composition are reported on as-fed basis.

${ }^{2}$ For the diet of d 1-21 and d 22-42, provided per kilogram of diet: vitamin A (all-trans retinol acetate), 12,500 IU; cholecalciferol, 2,500 IU; vitamin E (all-rac- $\alpha$-tocopherol acetate), $18.75 \mathrm{IU}$; vitamin $\mathrm{K}$ (menadione $\mathrm{Na}$ bisulfate), $5.0 \mathrm{mg}$; thiamin (thiamin mononitrate), $2.5 \mathrm{mg}$; riboflavin, $7.5 \mathrm{mg}$; vitamin $\mathrm{B}_{6}, 5.0 \mathrm{mg}$; vitamin $\mathrm{B}_{12}, 0.0025$ mg; pantothenate, $15 \mathrm{mg}$; niacin, $50 \mathrm{mg}$; folic acid, $1.25 \mathrm{mg}$; biotin, $0.12 \mathrm{mg}$; $\mathrm{Cu}$ $\left(\mathrm{CuSO}_{4} \times 5 \mathrm{H}_{2} \mathrm{O}\right), 10 \mathrm{mg} ; \mathrm{Mn}\left(\mathrm{MnSO}_{4} \times \mathrm{H}_{2} \mathrm{O}\right), 100 \mathrm{mg} ; \mathrm{Zn}\left(\mathrm{ZnSO}_{4} \times 7 \mathrm{H}_{2} \mathrm{O}\right), 100 \mathrm{mg} ; \mathrm{Fe}$ $\left(\mathrm{FeSO}_{4} \times 7 \mathrm{H}_{2} \mathrm{O}\right), 100 \mathrm{mg}$; I (KI), $0.4 \mathrm{mg} ; \mathrm{Se}\left(\mathrm{Na}_{2} \mathrm{SeO}_{3}\right), 0.2 \mathrm{mg}$.

\section{Immunohistochemical examination (SABC) of the IgA+ $B$ cells}

$\lg \mathrm{A}^{+} \mathrm{B}$ cell expression in the cecal tonsil was detected immunohistochemically using the Strept Avidin-Biotin Complex (SABC) method, as described by Wu et al. (2018a). Briefly, cecal tonsils were fixed in neutralized $10 \%$ buffered formalin for $48 \mathrm{~h}$ and routinely processed for embedding in paraffin and sectioned to $4 \mu \mathrm{m}$ pieices. Tissue sections were dewaxing, dehydrated or rehydrated through xylene and a graded series of ethanol, washed in distilled water and phosphate buffer saline (PBS). After blocking with 3\% endogenous peroxidase for $15 \mathrm{~min}$, the slides were overlaid with $10 \%$ normal goat serum (NGS) in PBS at $37^{\circ} \mathrm{C}$. Sections were incubated in primary antibodies (diluted 1:100) (polyclonal mouse anti-chicken IgA heavy chains, Southern Biotech-8330-01) overnight at $4{ }^{\circ} \mathrm{C}$ (for negative tissue controls, PBS was used instead of the primary antibody), and incubated with $1 \%$ biotinylated secondary antibody goat anti-mouse IgG (ZSGB-BIO SP Kit) for $1 \mathrm{~h}$ at $37^{\circ} \mathrm{C}$. Then the pieces were incubated 
with the HRP-streptavidin (ZSGB-BIO SP Kit) for 30 min at $37^{\circ} \mathrm{C}$. To visualize the immunoreaction, sections were immersed in diaminobenzidine hydrochloride (DAB). After hematoxylin counterstaining, the sections were examined with an Olympus AX 70 microscope (Olympus Corp., Tokyo, Japan) and photographed (magnification of $\times 400$ ). The $\lg A^{+} B$ cells (positive cells) were quantified by Image-Pro Plus 5.1 image analysis software. Each of the six chicken in each group were measured in five sections and each section was measured in five visions and averaged.

\section{Detection of the CD19 protein expression by Western Blot}

Cecal tonsil proteins were prepared for sodium dodecyl sulfate polyacrylamide gel electrophoresis (SDS-PAGE) under denaturing conditions. Proteins (3 $\mu$ l of sample at 1/10 dilution) were separated on polyacrylamide gels containing a stacking gel of $4 \%$ and a running gel of $10 \%$ and transferred to Immobilon-P (polyvinylidene difluoride (PVDF) millipore membranes (transfer buffer: $12.5 \mathrm{mM}$ Tris, $98 \mathrm{mM}$ glycine and 10\% methanol) at the transfer conditions of $150 \mathrm{~V}$ for $1.5 \mathrm{~h}$ at $4{ }^{\circ} \mathrm{C}$. Unstained markers for molecular weight from Sigma were included in all gels. After the transfer, the PVDF membrane was stained with $0.1 \%$ Red Ponceau with the aim of separating the lanes containing the molecular weight markers. Then the transfer membranes without molecular weights were washed with $150 \mathrm{mM}$ PBS, pH 7.2 plus $0.05 \%$ Tween-20 (PBS-T) and incubated in blocking buffer (PBS-T plus $5 \%$ non-fat dry milk) for $1 \mathrm{~h}$. Next, the membranes were incubated with anti-CD19 antibody (ab37808, Abcam, England) conjugated with peroxidase (1/1000 dilution, diluted with PBS-T) at $4{ }^{\circ} \mathrm{C}$ overnight. Three washes with PBS-T were performed after each step (30 min). Then membranes were incubated with the secondary antibody (1/5000 dilution, diluted with PBS-T) at room temperature for $1 \mathrm{~h}$, and then washed again. Once the process was finished, the blots were dried and immediately scanned. Protein bands were quantified using 1D image analysis software (Scion Image for Windows, Scion Corporation).

\section{Detection of the CD19 mRNA expression by qRT-PCR}

The cecal tonsils were obtained from six broilers in two groups at 14, 28, and 42 days of age. RNA was isolated from cecal tonsils using the RNA isolation kit (9108/9109, Takara, Japan). RNA was extracted and purified as described by $\mathrm{Wu}$ et al. (2014). RNA was quantified using the NanoDrop spectrophotometer (NanoDrop Technologies) and $0.5 \mu \mathrm{g}$ reverse-transcribed using the SuperScript III Reverse Transcriptase (Invitrogen). Quantitative realtime PCR was performed using an iCycler iQ Real-Time PCR detection system using iQ SYBR Green Supermix (BioRad). Expression level of target gene (CD19) was quantified and the expression of the $\beta$-actin housekeeping gene served as control. Gene expression values of the control group were used each week for gene expression calibration, respectively. With $2^{-\Delta \Delta C T}$ assay, the results were analyzed.

\section{Determination of the immunoglobulins (IgG, IgA, IgM and sIgA) contents in the cecal tonsil by ELISA}

The cecal tonsil tissues were collected and stored at $-80^{\circ} \mathrm{C}$ prior to the measurement of ELISA parameters. The immunoglobulin contents were determined using ELISA kit (MM-0912) as described by Wu et al. (2012b), and the result were calculated by the standard curve and were expressed as nanogram per millilitre. Briefly, $40 \mu \mathrm{l}$ of the samples were diluted and added to Standard (blank) wells and testing wells, and were incubated at $37^{\circ} \mathrm{C}$ for $30 \mathrm{~min}$. Then, the wells were washed with washing buffer 5 times and dried by pat. Then $50 \mu \mathrm{l}$ HRP-Conjugate reagent was added to each well, except blank well, and incubation and wash were conducted as the operation abovementioned. After that, Chromogen Solution A $50 \mu \mathrm{l}$ and Chromogen Solution $B$ were added to each well, and preserved evading the light for $15 \mathrm{~min}$ at $37^{\circ} \mathrm{C}$. The absorbance was read at 450nm after adding Stop Solution. Sample OD value was calculated according to the standard curve, and then the sample density was calculated based on the OD value.

\section{Statistical analysis}

Results were expressed as mean values \pm standard deviation $(\mathrm{M} \pm \mathrm{SD})$. Data were analyzed using Independent-Samples T test followed by Post Hoc, Tukey's HSD test. All Statistical analysis was performed using SPSS (SPSS for Windows, version 16.0, SPSS Inc, Chicago, Illinois). Differences were considered statistically significant when the calculated $p$-value was less than 0.05 and $p<0.01$ was considered highly significant.

\section{RESULTS}

\section{Changes in $\lg \mathrm{A}^{+} \mathrm{B}$ cells by Immunohisto- chemical examination (SABC)}

The results of immunohistochemical examination showed that $\lg A^{+} B$ positive cells were stained brown, 
and distributed in the diffuse lymphoid tissues and lymphoid follicles of the cecal tonsil as shown in Figure 1 a-f. The quantity of $\lg A^{+} B$ cells in the methionine deficiency group was significantly lower $(p<0.01)$ than that in the control group at 28 and 42 days of age, while no significant changes were observed at 14 days of age, which has been presented in Fig. 2 .

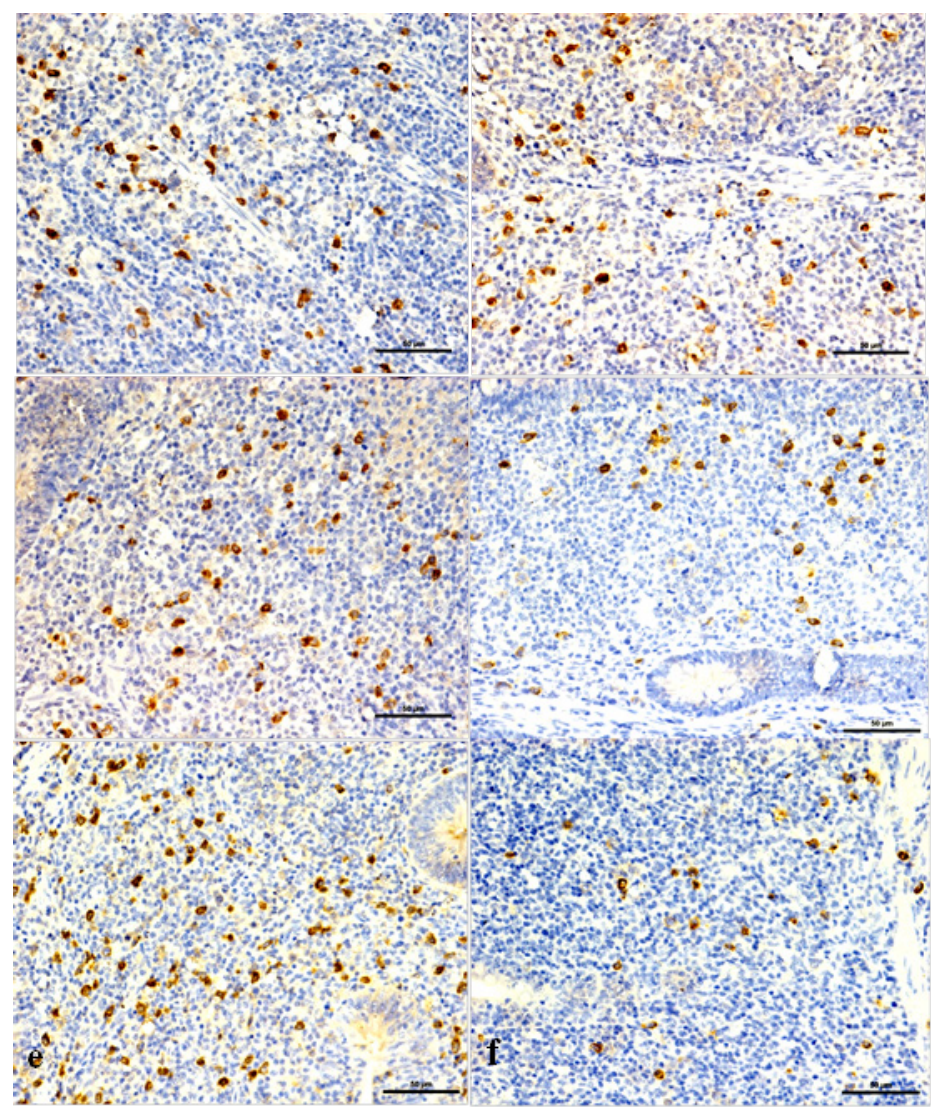

Figure $1-\lg \mathrm{A}^{+} \mathrm{B}$ cells in the diffuse lymphoid tissues and lymphoid follicles of the cecal tonsil

a. The $\lg \mathrm{A}^{+} B$ cells in the control group (bar $=50 \mu \mathrm{m}$ ) at 14 days of age. $b$. The $\lg \mathrm{A}^{+} B$ cells in the Met deficiency group at 14 days of age. There is no significant change (bar=50 $\mu \mathrm{m})$. c. The $\lg \mathrm{A}^{+} B$ cells in the control group at 28 days of age. $d$. The quantities of $\lg \mathrm{A}^{+}$ $B$ cells significantly decreased in the Met deficiency group at 28 days of age (bar $=50$ $\mu \mathrm{m})$. e. The $\lg \mathrm{A}^{+} B$ cells in the control group at 42 days of age. $f$. The quantities $\lg \mathrm{A}^{+} B$ cells significantly decreased in the Met deficiency group at 42 days of age (bar $=50 \mu \mathrm{m})$.

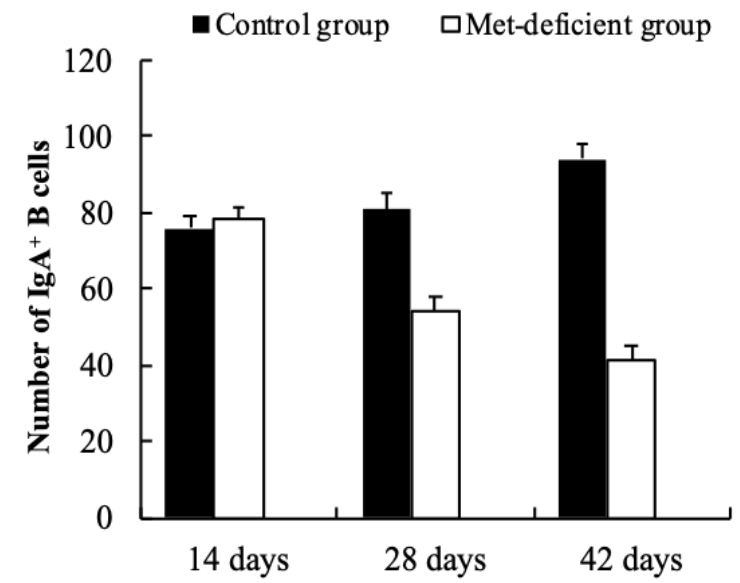

Figure $\mathbf{2}$ - The number of $\lg \mathrm{A}^{+} \mathrm{B}$ cells in cecal tonsil

\section{CD19 protein and mRNA expression level in cecal tonsil}

CD19 protein and mRNA expression levels in the cecal tonsil of methionine deficiency group were significantly decreased $(p<0.05$ or $p<0.01)$ at 28 and 42 days of age when compared with the control group (Fig. 3 a, b and c).

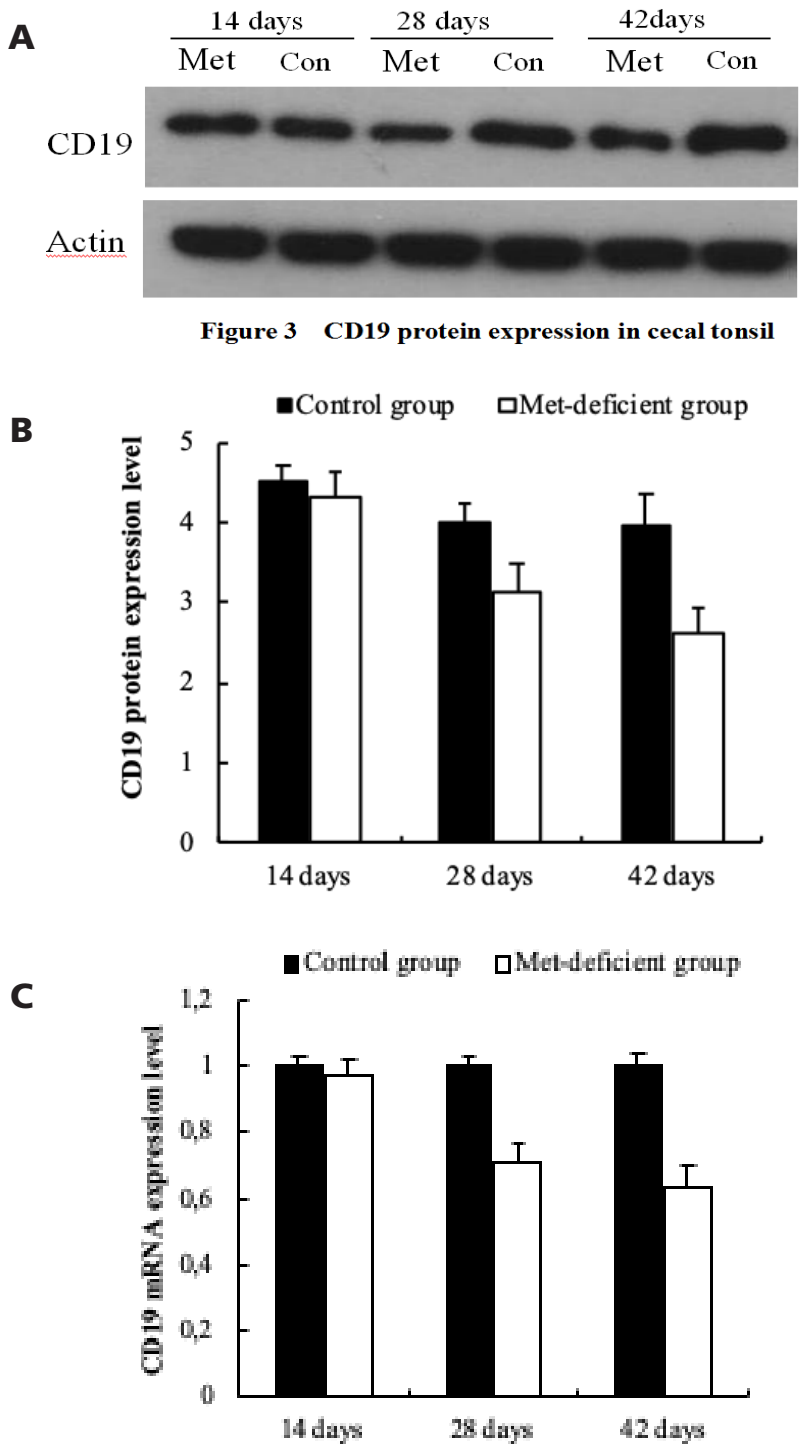

Figure 3 - a. CD19 protein expression in cecal tonsil; b. Relative expression of CD19 protein in cecal tonsil; c. CD19 mRNA expression level.

\section{Change of the $\operatorname{sig} A$, IgA, IgG and IgM contents $(\mu \mathrm{g} / \mathrm{ml})$ in cecal Tonsil}

As shown in Fig. 4 a-d, the slgA contents in the cecal tonsil of methionine deficiency group were significantly lower $(p<0.05$ or $p<0.01)$ than in the control group at 14, 28 and 42 days of age. And the $\lg A, \lg G$ and $\lg M$ contents showed the similar trend as they all significantly decreased $(p<0.05$ or $p<0.01)$ at 28 and 42 days of age. 
A

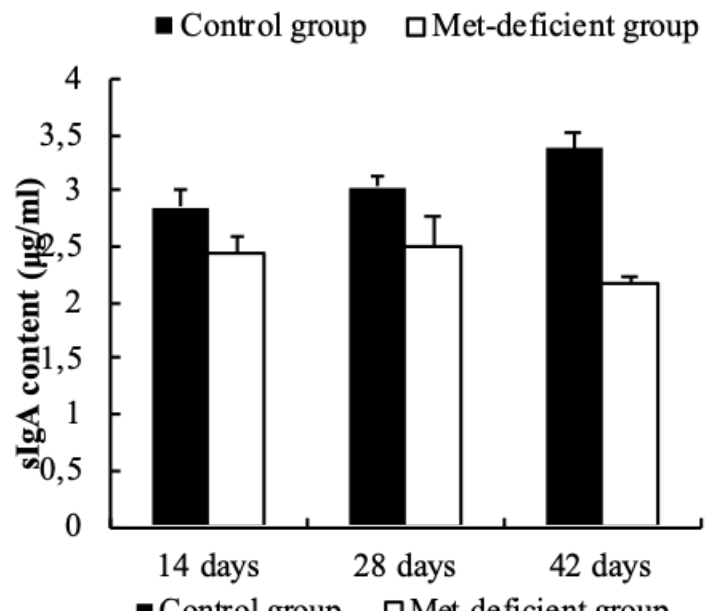

B

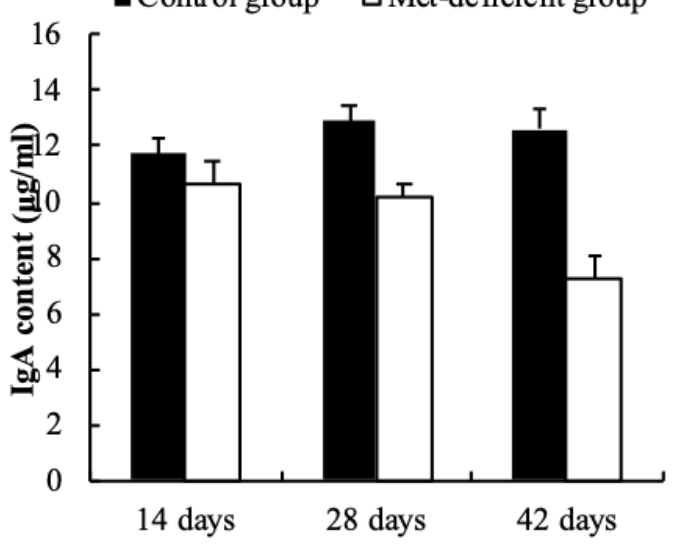

C

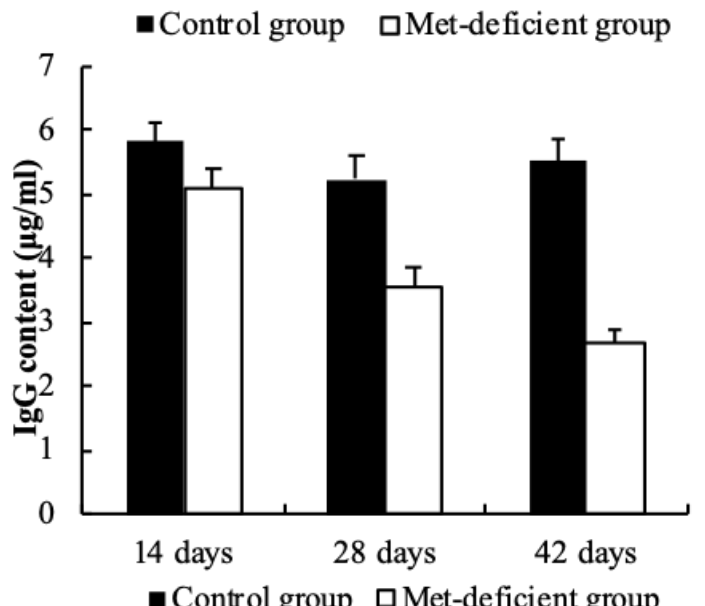

D

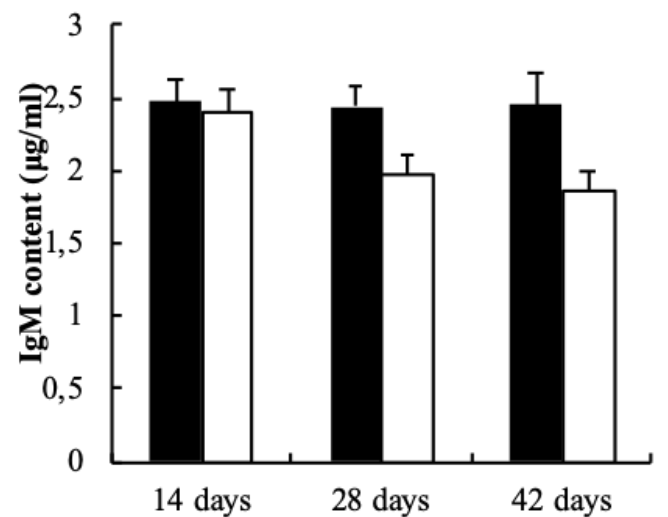

Figure 4 - Change of the slgA, IgA, lgG and IgM contents $(\mu \mathrm{g} / \mathrm{ml})$ in cecal Tonsil

\section{DISCUSSION}

In this study, the changes of $B$ lymphocytes count and the immunoglobulins contents including slgA, IgA, $\lg G$ and $\lg M$ in the cecal tonsil induced by methionine deficiency were observed. It is well known that the cecal tonsil is the major lymphoid tissue in avian cecum which not only participates in the antibody production but also is an important component in the mucosal immune system. The mucosal immune system in the cecal tonsil provides antigen-specific protection through B cells/antibodies and mucosal T cells, among which the B cells or the produced antibodies compose the humoral immunity (Clem \& AngelaS, 2011). B cells in the cecal tonsil can migrate into the lamina propria and develop into mature immunoglobulinproducing plasma cells (Fagarasan et al., 2011). In the present research, we found that the methionine deficiency reduced the population of B lymphocytes, the protein and mRNA expression of the CD19, and the immunoglobulin contents including slgA, $\lg A$, IgG and $\lg \mathrm{M}$.

$\lg G(\lg Y), \lg M$ and $\lg A$ are the major immunoglobulin classes in chicken (Mockett, 1986). IgA or secretory $\lg A(\operatorname{sg} A)$ is critical in protecting the mucosal surface against pathogenic microorganism (such as the toxins, viruses or bacteria) (Mockett, 1986). In addition, slgA plays important roles in the maintenance of mucosal homeostasis and the development of systemic immunity and may also determine the composition of the intestinal microbiota (Lammers et al., 2010). The decrease of IgA or slgA indicates that the protective role of the intestinal mucosal is impaired due to methionine deficiency. Furthermore, there is a close relationship between $B$ cells ( $\lg A^{+} B$ cells) and the humoral immune response, which implies that the reduction of $B$ cell population, slgA and $\lg A$ production will eventually impact the humoral immune function in the mucosal immunity of the cecal tonsil in broilers.

Chicken IgM is homologous to mammalian counterpart structurally and functionally (PerezCarbajal et al., 2010), which is the first antibody generated during the primary antibody response. IgM is also the major class of immunoglobulin expressed on the surface of chicken B lymphocytes (Boes, 2000). In the present study, the content of IgM in the cecal tonsil was decreased in the methonine deficiency group, which indicates that dietary methonine deficiency can impair primary immune response and has negative effects on B lymphocytes.

$\lg G$, which is secreted by B lymphocytes and was generated mainly in the secondary antibody 
responses, behaves like the homologue of mammalian IgG (Shimizu et al., 1992). IgG is the main antibody isotype found in blood and extracellular fluid, so it plays important roles in the protection of the body tissues (Hirano et al., 1986). Our present study showed that IgG contents decreased in the cecal tonsil of chicken fed on daily methionine deficiency diet. Thus, we speculated that dietary methionine deficiency could impact the clearance of the pathogens and the immune response. Our previous study also reported that the methionine deficiency significantly reduced the synthesis of $\lg G$ antibody in the duodenum and jejunum (Wu et al., 2018a).

In summary, our study suggested that methionine deficiency has negative effects on the $B$ lymphocytes and contents of immunoglobulins including slgA, $\lg A$, $\lg G$ and $\lg M$ in the cecal tonsil of broiler chicken. As a result, methionine might exert significant effect on the humoral immune function of intestinal mucosal immunity. This study provides the new experimental information and is pivotal for studying the effects of methionine on the intestinal function in human and other animals in the future.

\section{ACKNOWLEDGMENTS}

The authors would like to thank the co-workers of China West Normal University for their assistance in performing the experiment and the analysis. The study was supported by the programme for doctoral studies of China West Normal University (project no. 16E012).

\section{CONFLICT OF INTEREST}

The authors declare no competing financial interest. The use of chickens and all experimental procedures were approved by China West Normal University Animal Care and Use Committee.

\section{REFERENCES}

Boes M. Role of natural and immune IgM antibodies in immune responses. Molecular Immunology 2000;37(18):1141-1149.

Brosnan JT, Brosnan ME. The sulfur-containing amino acids:an overview. Journal of Nutrition 2006;136 (6 Suppl) :1636S-1640S.

Clem AS. Fundamentals of vaccine immunology. Journal of Global Infectious Diseases 2011;3(1):73-78.

Fagarasan S, Kinoshita K, Muramatsu M, Ikuta K, Honjo T. In situ class switching and differentiation to IgA-producing cells in the gut lamina propria. Nature 2011;413(6856);639-643.

Heidari M, Fitzgerald SD, Zhang H. Marek's disease virus-induced transient cecal tonsil atrophy. Avian Diseases 2014;58(2):262-270.
Hirano $T$, Yasukawa $K$, Harada $H$, Taga $T$, Watanabe $Y$, Matsuda $T$, et al. Complementary DNA for a novel human interleukin (BSF-2) that induces $B$ lymphocytes to produce immunoglobulin. Nature 1986;324(6092):73-76

Horvat S, Mlinaric-Majerski K, Glavas-Obrovac L, Jakas A, Veljkovic J Marczi S, et al. Tumor-cell targeted methionine-enkephalin analogues containing unnatural amino acids:design, synthesis, and in vitro antitumor activity. Journal of Medicinal Chemistry 2006;49(11):31363142.

Hoshi T, Heinemann SH. Regulation of cell function by methionine oxidation and reduction. Journal of Physiology 2010;531(1):1-11

Kim WK, Froelich CA, Patterson PH, Ricke SC. The potential to reduce poultry nitrogen emissions with dietary methionine or methionine analogues supplementation. World's Poultry Science Journal 2006;62(2):338-353.

Lammers A, Wieland WH, Kruijt L, Jansma A, Straetemans T, Schots A, et al. Successive immunoglobulin and cytokine expression in the small intestine of juvenile chicken. Developmental and Comparative Immunology 2010;34(12):1254-1262.

Li C, Li Z, Sletten E, Arnesano F, Losacco M, Natile G, et al. Methionine can favor DNA platination by trans-coordinated platinum antitumor drugs. Angewandte Chemie 2009;48(15):8497-8500

Li LG, Ruan T, Peng X, Wu BY. Immonosuppression of methionine deficiency on the number of $\operatorname{lgA}^{+} B$ cells and slgA content in the cecal tonsil of broiler chicken. Indian Veterinary Journal 2018;95 (2):26-28.

Mirzaaghatabar F, Saki AA, Zamani P, Aliarabi H, Matin HRH. Effect of different levels of diet methionine and metabolisable energy on broiler performance and immune system. Food and Agricultural Immunology 2011;22(2):93-103

Mockett APA. Monoclonal antibodies used to isolate IgM from chicken bile and avian sera and to detect specific IgM in chicken sera. Avian Pathology 1986;15(3):337-348.

Perez-Carbajal C, Caldwell D, Farnell M, Stringfellow K, Pohl S, Casco G, et al. Immune response of broiler chickens fed different levels of arginine and vitamin $\mathrm{E}$ to a coccidiosis vaccine and Eimeria challenge. Poultry Science 2010;89(9):1870-1877.

Rama Rao SV, Prahara JNK, Panda AK, Reddy MR. Interaction between genotype and dietary concentrations of methionine for immune function in commercial broilers. British Poultry Science 2003;44(1):104112.

Ramalingam A, Wang X, Gabello M, Valenzano MC, Mullin JM. Dietary methionine restriction improves colon tight junction barrier function and alters claudin expression pattern. AJP Cell Physiology 2010;299(5):C1028-1035.

Ruan T, Li LJ, Lyu YN, Lyu, Luo Q, Wu BY. Effect of methionine deficiency on oxidative stress and apoptosis in the small intestine of broilers. Acta Veterinaria Hungarica 2018;66(1):52-65

Shimizu M, Nagashima H, Sano K, Hashimoto K, Ozeki M, Tsuda K, et al. Molecular stability of chicken and rabbit immunoglobulin $\mathrm{G}$. Journal of the Agricultural Chemical Society of Japan 1992;56(2):270-274

Tesseraud S, Everaert N, Ezzine SB, Collin A, Métayer-Coustard S, Berri C. Manipulating tissue metabolism by amino acids. World's Poultry Science Journal 2011;67(2):243-252

Wu BY, Cui HM, Peng X, Fang J, Cui W, Liu XD. Pathology of spleen in chickens fed on a diet deficient in methionine. Health 2012a;4(1):3238

Wu BY, Cui HM, Peng X, Fang J, Cui W, Liu XD. Effect of methionine deficiency on the thymus and the subsets and proliferation of peripheral blood t-cell, and serum il-2 contents in broilers. Journal of Integrative Agriculture 2012b;11(6):1009-1019. 
Wu BY, Cui HM, Peng X, Fang J, Cui W, Liu XD. Pathology of bursae of Fabricius in methionine-deficient broiler chickens. Nutrients 2013;5(3):877-886.

Wu BY, Li LY, Ruan T, Peng X. Effect of methionine deficiency on duodenal and jejunal $\lg \mathrm{A}^{+} \mathrm{B}$ cell count and immunoglobulin level of broilers. Iranian Journal of Veterinary Research 2018a;19(3):165-171.

Wu BY, Zhu M, Ruan T, Li LJ, Lyu YN. Oxidative stress, apoptosis and abnormal expression of apoptotic protein and gene and cell cycle arrest in the cecal tonsil of broilers induces by dietary methionine deficiency. Research in Veterinary Science 2018b;121:65-75.
Wu BY, Cui HM, Peng X, Fang J, Zuo ZC, Deng JL, et al. Dietary nickel chloride induces oxidative stress, apoptosis and alters Bax/BCl-2 and caspase-3 mRNA expression in the cecal tonsil of broilers. Food and Chemical Toxicology 2014;63:18-29.

Yen CE, Mar MH, Craciunescu CN, Edwards LJ, Zeisel SH. Deficiency in methionine, tryptophan, isoleucine, or choline induces apoptosis in cultured cells. The Journal of Nutrition 2002;132(7):1840-1847. 
